The March of Spare Time 
This page intentionally left blank 


\section{The March of Spare Time}

The Problem and Promise of

Leisure in the Great Depression

SUSAN CURRELL

$\overline{\text { PENN }}$

University of Pennsylvania Press

Philadelphia 
Copyright ( 2005 University of Pennsylvania Press

All rights reserved

Printed in the United States of America on acid-free paper

$\begin{array}{llllllllll}10 & 9 & 8 & 7 & 6 & 5 & 4 & 3 & 2 & 1\end{array}$

Published by

University of Pennsylvania Press

Philadelphia, Pennsylvania 19104-4011

Library of Congress Cataloging-in-Publication Data

Currell, Susan.

The march of spare time : the problem and promise of leisure in the Great Depression / Susan Currell.

p. $\mathrm{cm}$.

Includes bibliographical references and index.

ISBN 0-8122-3859-1 (cloth : alk. paper)

1. Leisure-United States-History-20th century.

2. Depressions-1929-United States. 3. United States-Social conditions-1933-1945. I. Title.

GV53.C79 2005

790.1'0973'09043-dc22 